\title{
Performance Analysis of a Dual-Fuel Sugar Based Solid Rocket Propellant
}

\author{
Gbadebo Omoniyi Adeniyi, Inkechukwu Nkere, Lanre Moshood Adetoro, and Olusegun Samuel \\ Sholiyi
}

\begin{abstract}
The effects of dual-fuel on improving the ballistic efficiency of a low energy sugar-based solid rocket propellant were investigated in this paper. This was achieved by establishing a threshold proportion of sucrose to sorbitol that provided the highest ballistic efficiency, using a beam load cell (model single-point $2,000 \mathrm{~kg}$ linearly defined by $0-20 \mathrm{kN}$ force, with \pm .005 percent precision). Seven different propellant formulations were prepared, loaded into the rocket motor and tested for performance. The major performance parameters of interest were the thrust, total impulse, burn time, delivered specific impulse, delivered characteristic velocity, and the chamber pressure. The formulations tested were potassium nitrate-sucrose propellant $\left(65 \% \quad \mathrm{KNO}_{3}\right.$ and $35 \%$ sucrose $\left(\mathrm{C}_{12} \mathrm{H}_{22} \mathrm{O}_{11}\right)$ ) (KNSU); potassium nitrate-sorbitol propellant $\left(65 \% \mathrm{KNO}_{3}\right.$ and $35 \%$ sorbitol $\left.\left(\mathrm{C}_{6} \mathrm{H}_{14} \mathrm{O}_{6}\right)\right)(\mathrm{KNSB})$; modified potassium nitrate-sucrose propellant $\left(65 \% \mathrm{KNO}_{3}, 32 \%\right.$ sucrose $\left(\mathrm{C}_{12} \mathrm{H}_{22} \mathrm{O}_{11}\right)$ ), and 3\% carbon (C) (MODKNSU); potassium nitrate-sucrose-sorbitol propellant $\left(65 \% \mathrm{KNO}_{3}, 25 \%\right.$ sucrose (C12H22O11)), and $10 \%$ sorbitol $\left(\mathrm{C}_{6} \mathrm{H}_{14} \mathrm{O}_{6}\right)$ (KNERK); potassium nitrate-sucrose-sorbitol-carbon propellant $(65 \%$ $\mathrm{KNO}_{3}, 24 \%$ sucrose $\left(\mathrm{C}_{12} \mathrm{H}_{22} \mathrm{O}_{11}\right), 10 \%$ sorbitol $\left(\mathrm{C}_{6} \mathrm{H}_{14} \mathrm{O}_{6}\right)$, and $1 \%$ carbon (C)) (MODKNERK); and finally a propellant made from $\mathrm{KNO}_{3}$, sucrose $\left(\mathrm{C}_{12} \mathrm{H}_{22} \mathrm{O}_{11}\right)$, sorbitol $\left(\mathrm{C}_{6} \mathrm{H}_{14} \mathrm{O}_{6}\right)$, carbon (C) and iron II oxide $\left(\mathrm{Fe}_{2} \mathrm{O}_{3}\right)$ combinations in $65,30,3,1,1 \%$ proportion respectively. The novel result obtained from these experiments was applied to boost the performance of a KNSB rocket propellant motor during a rocket launch experiment. Both static and dynamic rocket motor internal ballistic parameters were then compared. The measured delivered motor average thrust and the effective propellant burn times were recorded as: $(164.15 \mathrm{~N}, 3.97 \mathrm{~s}) ;(102.95 \mathrm{~N}, 6.53 \mathrm{~s}) ;(65.66 \mathrm{~N}$, $9.38 \mathrm{~s}) ;(79.09 \mathrm{~N}, 3.77 \mathrm{~s}) ;(243.98 \mathrm{~N}, 3.77 \mathrm{~s})$ and $(92.6 \mathrm{~N}, 5.89 \mathrm{~s})$ respectively. The MODKNERK, was established to produce a most efficient motor and with the full delivery of its ballistic energy. It was also established, that the ballistic and rocket motor efficiency of a lower energy rocket motor can be improved by starting the ignition of such motor with fast burning dual-fuel rocket propellant (MODKNERK).
\end{abstract}

Index Terms - KNSU, KNSB, MODKNSU, KNERK, MODKNERK, Low Energy Oxidizer, Fuel, Additives, Thrust, Specific Impulse.

\section{INTRODUCTION}

The challenges faced in developing high energy rocket propellants are enormous [1], thus, keeping the use of low energy sugar-based propellant in amateur rocketry still very

Published on February 7, 2021

Gbadebo Omoniyi Adeniyi, Centre for Space Transport and Propulsion, Nigeria.

(e-mail: omogbadebo2002@yahoo.com)

Inkechukwu Nkere, Centre for Space Transport and Propulsion, Nigeria (e-mail: dreamsr4life57@ gmail.com)

Lanre Moshood Adetoro, Centre for Space Transport and Propulsion, Nigeria.

(e-mail: adetoro3@yahoo.com)

Olusegun Samuel Sholiyi, Centre for Space Transport and Propulsion, Nigeria.

(e-mail: sharemust@gmail.com) popular. Challenges such as non-availability of materials, high cost of high energy chemicals, machinery and tools. Also, most important challenge is the safety of lives and properties, because most high energy rocket propellants are carcinogenic and spontaneous in nature. Sugar-based propellants or rocket candy is a type of rocket propellant for model rockets [2]. It has primarily sugar as a fuel and low energy nitrate as oxidizer. The components of the propellant in some cases could be the fuel, the oxidizer and the additives [3]. In this study, the fuel is a sugar (sucrose, dextrose, maltose, or Sorbitol (sugar alcohol). Sucrose is the most commonly used among the sugar-based fuel [3]. The possible oxidizers with this fuel are potassium nitrate $\left(\mathrm{KNO}_{3}\right)$ or sodium nitrate $\left(\mathrm{NaNO}_{3}\right)$. The additives are substances of different types (Sulfur, charcoal, aluminum, magnesium, iron oxide etc.) which may act as an opacifier, catalysts, suppressants or burn rate modifiers [4].

Using sucrose as fuel in a sugar propellant is considered as an excellent active component; however, it is limited with its inconsistent characteristics between batches of propellant due to its persistent caramelization and excessively high pressure index [5]. Burning rate is sensitive to the value of the pressure exponent; $n$. High values of pressure index leads to high changes in burning rate with relatively high changes in chamber pressure, and with potentially catastrophic consequences [6]. Efforts were being made in the past by replacing it with other fuels such as sorbitol, dextrose etc. [3]. This provided an excellent working time during manufacturing and longer burning time during combustion than sucrose. However, the plateau and the mesa effects of these fuels and low burning rate of the propellants are also serious limitations. Burn rate is largely affected by chamber pressure [7] and [8]. Sucrose fuel sugar propellant (KNSU) obeys the saint Robert equation: $r=$ $a P^{n}$ [9]. Experience has shown that small fluctuation in combustion is translated into significant pressure variation. Also, accidental increases in the propellant burning surface area most often lead to overpressure that results to explosion of the motor [10] and [11]. However, potassium nitratesorbitol propellant (KNSB) and potassium nitrate- dextrose propellant (KNDX) deviate from such behaviour (burning rate independent of pressure within a given range of pressure and burning rate decreases with increase in pressure respectively) [12].

According to some authors, modifying the burning rate could be achieved by decreasing the oxidizer particle size, increasing or reducing the percentage of oxidizer $(\mathrm{O} / \mathrm{F}$ ratio variation), adding a burn rate catalyst or suppressant, operating the motor at a lower or higher chamber pressure with the understanding that burn rate of most propellants is strongly influenced by the oxidizer/fuel ratio (O/F). Unfortunately, modifying the burn rate by this means is 
quite limited, as the performance of the propellant, as well as mechanical properties, are also greatly affected by the $\mathrm{O} / \mathrm{F}$ ratio [13] and [14]. No doubt, the best and most effective means of increasing the burn rate is the addition of a catalyst to the propellant mixture. The chemistry of the catalysts enhances the fuel and oxidizer decomposition, accelerating vaporized fuel reactions in the gas phase of the combustion zone and increasing heat transfer at the propellant surface layer [15]. Some catalysts increase burn rate by increasing the burn rate coefficient; others tend to increase the pressure exponent (making the propellant more sensitive to pressure changes). Ferric oxide $\left(\mathrm{Fe}_{2} \mathrm{O}_{3}\right)$, copper oxide $(\mathrm{CuO})$, manganese dioxide $(\mathrm{MnO} 2)$ are commonly used catalysts in ammonium perchlorate, AP based composite propellants [16]. Potassium dichromate $\left(\mathrm{K}_{2} \mathrm{Cr}_{2} \mathrm{O}_{7}\right)$ or ammonium dichromate $\left(\left(\mathrm{NH}_{4}\right)_{2} \mathrm{Cr}_{2} \mathrm{O}_{7}\right)$ for ammonium nitrate (AN) based mixtures [17]. Ferric Oxide $\left(\mathrm{Fe}_{2} \mathrm{O}^{3}\right)$, Iron sulphate $\left(\mathrm{Fe}_{2} \mathrm{SO}_{4}\right)$, carbon $(\mathrm{C})$ and potassium dichromate for $\mathrm{KN}-\mathrm{Sugar}$ propellants [3].

Several attempts were made by some authors towards improving the thermodynamics and ballistic properties of sugar-based propellants. Foltran [18], worked on the performance of KNSU, whose composition is 65 wt \% $\mathrm{KNO}_{3}$ and 35 wt $\% \quad \mathrm{C}_{12} \mathrm{H}_{22} \mathrm{O}_{11}$, cold-manufactured by mechanical press. The behaviour of density $(\rho)$ and burning rate $(r)$ as function of compression pressure $(\mathrm{Pc})$ for the propellant grain manufacturing was also determined. It was reported that both parameters depend on Pc, according to quadratic polynomial functions and the mass flux per unit area was a constant. Kumar [19] reported that the inclusion of aluminium shows an agreeable increase in specific impulse and thrust co-efficient. The specific impulse was found to be 184.9 seconds with the thrust co-efficient of 2.1. The combustion temperature was also found to be increased by $200{ }^{\circ} \mathrm{C}$ with inclusion of aluminium. This increase in temperature is responsible for the high temperature of exhaust gases which increases the thrust produced. Olaoye [20] simulated the ideal theory equations which govern the working of the rocket using MATLAB and creating a virtual way of determining and improving its performance before it is being launched. By so doing, certain dangers and expenses can be avoided. The parameters determined through MATLAB were in close agreement with the experimental results by Nakka. The predicted operating pressure of KNO3 propellant is $19 \mathrm{MPa}$, this is not beyond what stainless steel material can withstand and the thrust coefficient are in a range of 1.5 and 1.9. It was extended to predict variation of pressure with time and the thrust generated which could carry the load effectively. The burning rate of potassium nitrate and sucrose $(65 / 35 \%)$ at 1 and $7 \mathrm{~atm}$ pressures using a different oxidizer/fuel mass ratio, were $2.184 \mathrm{~mm} / \mathrm{sec}$ and $3.791 \mathrm{~mm} / \mathrm{sec}$ respectively as reported by Mohammad [21].

Yang [7] presented the detail process of a solid fuel rocket engine, from the initial hypotheses based on rocket engines with similar characteristics using simulation software to predict the performance of a solid rocket propellant. Both the temperature of combustion products and the characteristic exhaust velocity which were simulated by the model were both validated. The work also revealed that the products of the KNSU burning reaction are mostly carbon dioxide, carbon monoxide and water. The literatures have established that changing the ratios of the active components of solid rocket propellant formulations, impacts the thrust, burning rate, chamber temperature, propellant burn time and chamber pressure of a rocket engine during combustion [22]-[24]. Literature also has it that a large imbalance in the ratio of active propellant components will decrease the burn rate and as the ratio becomes larger, the burn rate continues to decrease further [25].

Therefore, in this paper, efforts were made towards looking for a mid-characteristic point for both available fuels (sucrose and sorbitol). This was done by searching for a threshold ratio of sucrose to sorbitol appropriate as dualfuel of good propellant formulation for rocket motor performance.

\section{MATERIALS AND METHODS}

Six different experiments were conducted with different sugar-based rocket propellant formulations. The first two formulations were based on the standard formulations postulated by Richard Nakka. Both formulations were made of potassium nitrate and sucrose (KNSU) and potassium nitrate and sorbitol (KNSB) respectively. While, in the other four formulations, both the effects of additives [26] and dual-fuel on the performance parameters of the rocket propellant were tested.

\section{A. Materials and Formulations}

Experiment 1: the formulation for this experiment was made of potassium and sucrose (potassium nitrate - sucrose propellant $\left(65 \% \quad \mathrm{KNO}_{3}\right.$ and $35 \%$ sucrose $\left.\left(\mathrm{C}_{12} \mathrm{H}_{22} \mathrm{O}_{11}\right)\right)$ (KNSU). This formulation was chosen for its optimum propellant performance (3). Potassium nitrate is the oxidizer while sucrose serves as the fuel. The combustion equation for this combination is given in equation (1).

$$
\begin{aligned}
& 6.41 \mathrm{KNO}_{3(s)}+1.027 \mathrm{C}_{12} \mathrm{H}_{22} \mathrm{O}_{11(s)} \rightarrow 7.97 \mathrm{H}_{2} \mathrm{O}_{(g)}+ \\
& 5.33 \mathrm{CO}_{(g)}+3.88 \mathrm{CO}_{2(g)}+3.205 \mathrm{~N}_{2(g)}+3.182 \mathrm{H}_{2(g)}+ \\
& 3.06 \mathrm{~K}_{2} \mathrm{CO}_{3(l)}+0.29 \mathrm{KOH}_{(g)}
\end{aligned}
$$

Experiment 2: potassium nitrate-sorbitol propellant (65\% $\mathrm{KNO}_{3}$ and $35 \%$ sorbitol $\left.\left(\mathrm{C}_{6} \mathrm{H}_{14} \mathrm{O}_{6}\right)\right)$ (KNSB). This formulation was similar to KNSU propellant in experiment 1 only that the fuel was sorbitol $(65 / 35 \%)$ and the stoichiometric equation is expressed in equation (2).

$$
\begin{aligned}
& 6.42 \mathrm{KNO}_{3(s)}+1.92 \mathrm{C}_{6} \mathrm{H}_{14} \mathrm{O}_{6(s)} \rightarrow 9.28 \mathrm{H}_{2} \mathrm{O}_{(g)}+ \\
& 4.78 \mathrm{CO}_{(g)}+4.11 \mathrm{H}_{2(g)}+3.59 \mathrm{CO}_{2(g)}+3.21 \mathrm{~N}_{2(g)}+ \\
& 3.16 \mathrm{~K}_{2} \mathrm{CO}_{3(l)}+0.1 \mathrm{KOH}_{(g)}
\end{aligned}
$$

Experiment 3: the role of carbon as the opacifier and also as a control for hygroscopic problem was tested in the modified potassium nitrate-sucrose propellant $\left(65 \% \mathrm{KNO}_{3}\right.$, $32 \%$ sucrose $\left(\mathrm{C}_{12} \mathrm{H}_{22} \mathrm{O}_{11}\right)$, and $3 \%$ carbon (C)) (MODKNSU). This was achieved by doping KNSU propellant with carbon. Equation (3) gives the combustion reaction of such combinations. 
$6.42 \mathrm{KNO}_{3(s)}+0.936 C_{12} \mathrm{H}_{22} \mathrm{O}_{11(s)}+2.478 C_{(s)} \rightarrow$

$7.16 \mathrm{CO}_{(g)}+6.04 \mathrm{H}_{2} \mathrm{O}_{(g)}+4.19 \mathrm{H}_{2(g)}+3.39 \mathrm{CO}_{2(g)}+$

$3.21 \mathrm{~N}_{2(g)}+3.16 \mathrm{~K}_{2} \mathrm{CO}_{3(l)}+0.1 \mathrm{KOH}_{(g)}$

Experiment 4: several iterations (using thermal equilibrium code) were carried out to determine the optimum threshold ratio for optimum combination of both sucrose and sorbitol in potassium nitrate-sucrose-sorbitol rocket propellant formulation named KNERK. More so, this combination investigates the implications of trading on both strength and weakness of the two fuel. The optimum composition: $65 \%$ potassium nitrate $\left(\mathrm{KNO}_{3}\right), 25 \%$ sucrose $\left(\mathrm{C}_{12} \mathrm{H}_{22} \mathrm{O}_{11}\right)$, and $10 \%$ sorbitol $\left(\mathrm{C}_{6} \mathrm{H}_{14} \mathrm{O}_{6}\right)$. Arriving at this propellant formulation was not only based on the propellant performance index but also on ease of manufacturing, mechanical strength of the propellant, the combustion plume, the burning behaviour of the propellant and the dynamics of the pressure built-up during combustion.

$6.41 \mathrm{KNO}_{3(s)}+0.83 \mathrm{C}_{12} \mathrm{H}_{22} \mathrm{O}_{11(s)}+0.37 \mathrm{C}_{6} \mathrm{H}_{14} \mathrm{O}_{6(s)} \rightarrow$
$8.16 \mathrm{H}_{2} \mathrm{O}_{(g)}+5.25 \mathrm{CO}_{(g)}+3.83 \mathrm{CO}_{2(g)}+3.27 \mathrm{H}_{2(g)}+$
$2.05 \mathrm{~N}_{2(g)}+3.08 \mathrm{~K}_{2} \mathrm{CO}_{3(l)}+0.25 \mathrm{KOH}_{(g)}$

Experiment 5: potassium nitrate-sucrose-sorbitol-carbon propellant formulation $\left(65 \% \quad \mathrm{KNO}_{3}, \quad 24 \%\right.$ sucrose $\left(\mathrm{C}_{12} \mathrm{H}_{22} \mathrm{O}_{11}\right), 10 \%$ sorbitol $\left(\mathrm{C}_{6} \mathrm{H}_{14} \mathrm{O}_{6}\right)$, and $1 \%$ carbon $\left.(\mathrm{C})\right)$ (MODKNERK). The potassium nitrate as the oxidizer, dualfuel (sucrose/sorbitol) and an additive carbon. This formulation was also meant to trade-off both the strength and weakness of the two fuel and also to verify the implication of carbon as the opacifier. The combustion equation for this propellant is given in equation (5).

$6.418 \mathrm{KNO}_{3(s)}+0.712 \mathrm{C}_{12} \mathrm{H}_{22} \mathrm{O}_{11(s)}+0.531 \mathrm{C}_{6} \mathrm{H}_{14} \mathrm{O}_{6(s)}+$
$0.8 C_{(s)} \rightarrow 7.69 \mathrm{H}_{2} \mathrm{O}_{(g)}+5.76 \mathrm{CO}_{(g)}+3.78 \mathrm{H}_{2(g)}+$
$3.64 \mathrm{CO}_{2(g)}+3.209 \mathrm{~N}_{2(g)}+3.13 \mathrm{~K}_{2} \mathrm{CO}_{3(l)}+0.158 \mathrm{KOH}_{(g)}$

Experiment 6: the effect of iron oxide as catalyst on MODKNERK was tested. The propellant formulation was made of the $\mathrm{KNO}_{3}$, sucrose $\left(\mathrm{C}_{12} \mathrm{H}_{22} \mathrm{O}_{11}\right)$, sorbitol $\left(\mathrm{C}_{6} \mathrm{H}_{14} \mathrm{O}_{6}\right)$, carbon and iron II oxide $\left(\mathrm{Fe}_{6} \mathrm{O}_{3}\right)$ combinations, in $65,30,3,1,1 \%$ proportion respectively.

$$
\begin{aligned}
& 6.41 \mathrm{KNO}_{3(\mathrm{~S})}+0.902 \mathrm{C}_{12} \mathrm{H}_{22} \mathrm{O}_{6(s)}+0.125 \mathrm{C}_{6} \mathrm{H}_{14} \mathrm{O}_{6(s)}+ \\
& 0.756 \mathrm{C}_{(s)}+0.06 \mathrm{Fe}_{2} \mathrm{O}_{3(s)} \rightarrow 7.47 \mathrm{H}_{2} \mathrm{O}_{(g)}+5.49 \mathrm{CO}_{(g)}+ \\
& 3.75 \mathrm{CO}_{2(g)}+3.21 \mathrm{H}_{2(g)}+3.09 \mathrm{~K}_{2} \mathrm{CO}_{3(l)}+0.23 \mathrm{KOH}_{(g)}+ \\
& 0.12 \mathrm{FeO}_{(s)}+
\end{aligned}
$$

Experiment 7 (Application): finally, the novel result obtained from these experiments was applied to boost the performance of a KNSB rocket propellant motor through a rocket launch experiment. This was done in a hybrid arrangement where the propellant bates in the combustion chamber were of two different grain formulations (MODKNERK and KNSB). The number of bates were three. The first bate was a dual-fuel formulation MODKNERK, with a dimension of $0.187 \mathrm{~m}$ long, $0.11 \mathrm{~m}$ outer diameter and $0.05 \mathrm{~m}$ core diameter while the other two bates were made of formulation in KNSB propellant (Fig.
1). The dimensions of the bates were similar to the MODKNERK. Four different static combustion tests were conducted using a data acquisition system. The tested motor was used to launch a rocket named TL_4) (Fig. 2). The static parameters were eventually compared to the dynamic flight parameters.

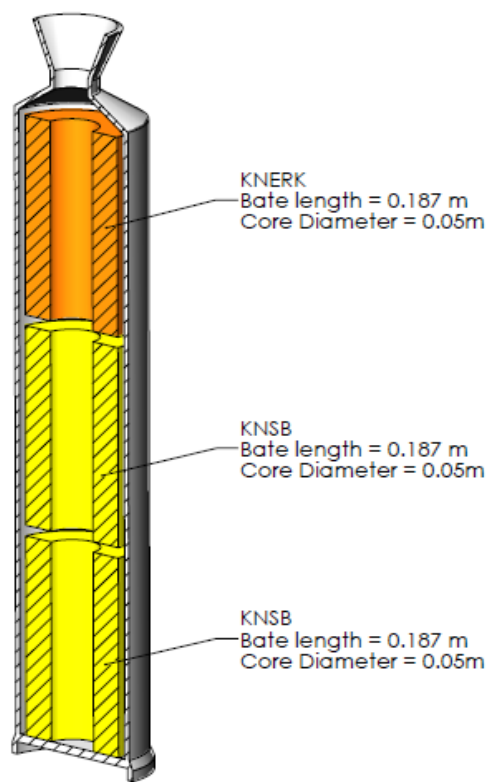

Fig. 1. CAD cross section of a loaded rocket motor

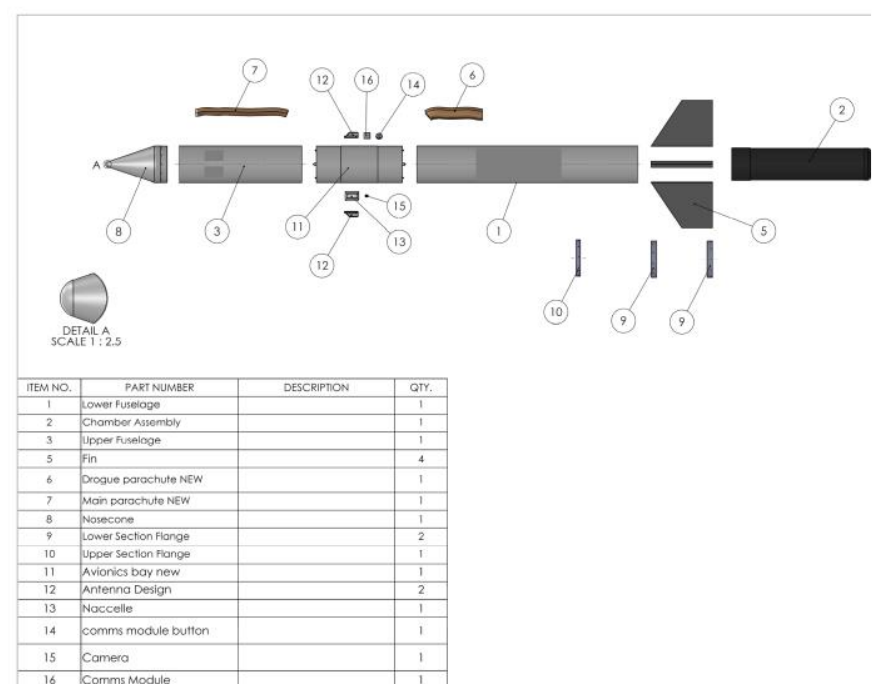

Fig. 2. CAD_TL_4 rocket.

\section{B. Machineries and Tools}

The following tools were used in the manufacture of the propellants: the mixer (Fig. 3) for proper mixing and blending of the propellant components, and the moulds for casting and forming the propellant grain geometry (Fig. 4 a and $b$ ). During casting, the propellant was vibrated using a vibrator. This was meant to ensure the release of the possible air traps and proper compaction of the propellant. 


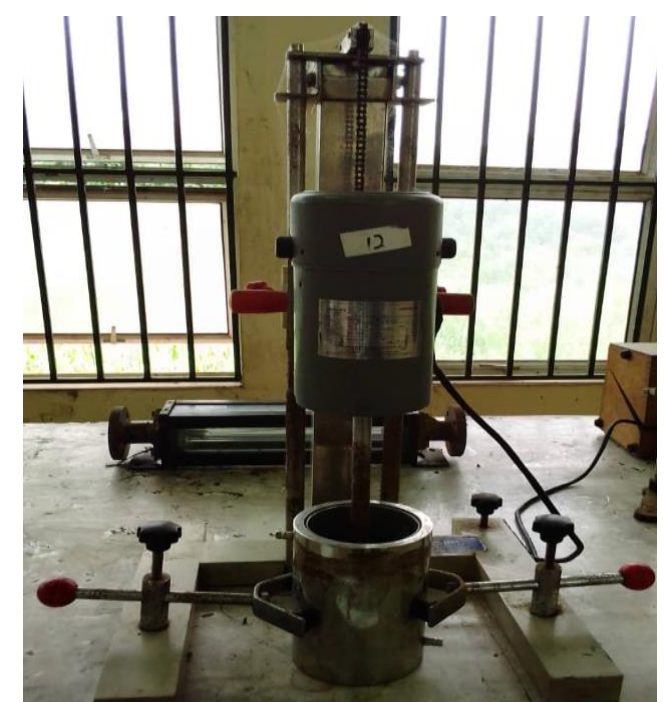

Fig. 3. The propellant mixer (Model: SWFS-400, Power: 400 watts, Voltage: 220 volts/50Hz, Size: $550 \times 390 \times 760$ and Rotation speed: $0-8000 \mathrm{rpm}$ ).

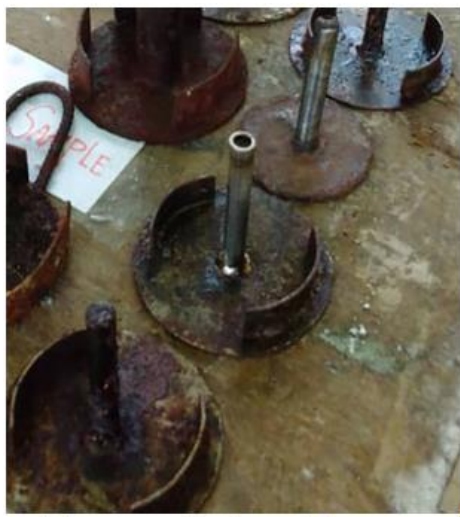

(a) propellant moulds

\section{Manufacturing Procedures}

Two different methods were adopted in the rocket propellant preparations: re-crystallization method for potassium nitrate and sucrose formulation while melting point method using oil bath for potassium nitrate, sorbitol and other additives formulations. Thus, resulting into the production of the propellants (Fig. 5).

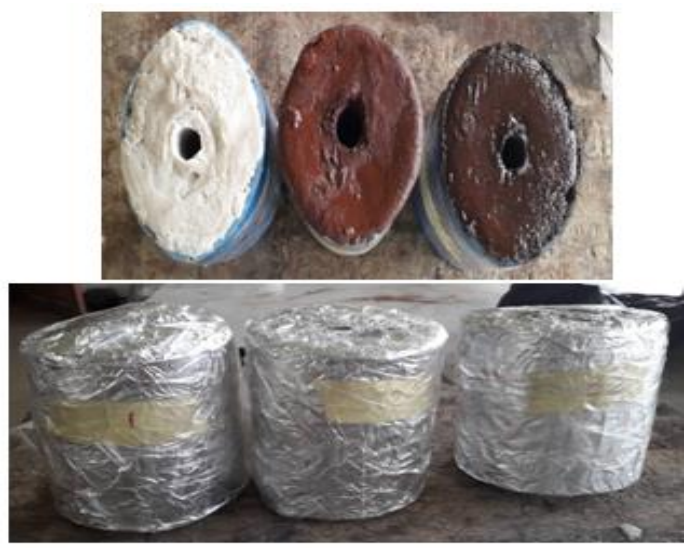

Fig. 5. Samples of the manufactured propellants.

Re-crystallization method: potassium nitrate and sucrose were weighed out in the ratio $65 / 35 \%$ composition separately into containers and premixed. The mixture was then put into the reactor and water was added to dissolve it, in the ratio of 2:3 according to Nakka [3]. It was then heated up using gas burner and stirred with a wooden stirrer. It was mixed thoroughly using a wooden stirrer until uniform mixture was achieved. Temperature of the propellant slurry inside the mixer was also monitored and regulated at temperature less than $130{ }^{\circ} \mathrm{C}$ to prevent caramelization of the propellant. The mixing was allowed to proceed until the propellant is ready for casting when it was observed that all ingredients had been uniformly mixed together and a semi solid mixture (slurry) has been achieved. The propellant slurry (semi-solid) was then cast into a casting mould using the cast-in-place-core method to form the grain geometry and vibrated on a vibrator for about $10 \mathrm{~s}$ to ensure consistency in density and relatively flaw-free propellant grain. The casting mould was removed after 2 hours, and the propellant was allowed to cure (solidify and dry) usually for 48 hours or more.

Melting point method: Both potassium nitrate $(65 \%)$ and sorbitol $(35 \%)$ were weighed and pre-mixed in a container. The temperature of the oil bath was raised to 100 degree Celsius, adequate enough to melt the premixed potassium nitrate and sorbitol. The propellant was added gradually to the reactor heated up by oil bath and was stirred thoroughly until all lumps disappeared. The temperature of the propellant slurry inside the mixer was also monitored and regulated at temperature less than $130^{\circ} \mathrm{C}$ to prevent caramelization of the propellant. The mixing was also allowed to proceed as stated in the re-crystallization method. It should be noted that, there was no need for a vibrator and presser because the slurry of KNSB is less viscous than that of the KNSU. The casting mould was then removed after about 12 hours, and the propellant was allowed to cure (solidify and dry) usually for 48 hours or more.

\section{Motor Parameters}

The rocket motor that was used for the experimentation has the following components: the bulk head, the cylindrical channel and the nozzle. All made of mild steel with a total mass of $4.5 \mathrm{~kg}$. It is characterized with the following parameters as shown in Fig. 6: the chamber length of $0.2 \mathrm{~m}$, the effective chamber length of $0.12 \mathrm{~m}$, the chamber internal diameter is $0.104 \mathrm{~m}$ and the chamber external diameter is $0.107 \mathrm{~m}$. The chamber thickness, the throat diameter, the exit diameter and the nozzle thickness are $0.0032 \mathrm{~m}, 0.02 \mathrm{~m}$, $0.0327 \mathrm{~m}$ and $0.002 \mathrm{~m}$ respectively. The convergent length and the divergent length are $0.04 \mathrm{~m}$ and $0.025 \mathrm{~m}$ accordingly while their respective angles are 45 degrees and 15 degrees respectively [27].
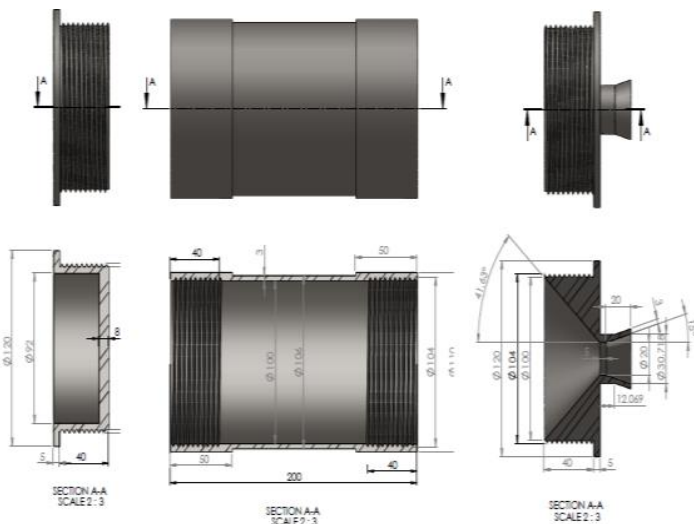

Fig. 6. CAD drawing of the rocket motor. 


\section{E. Ballistic Evaluation Test}

Ballistic evaluation tests were conducted at the Space Transport and Propulsion Centre, Lagos, Nigeria, using a motor test stand. An industrial-grade Rocket Motor Test Stand (Fig. 7) developed at the Centre, was used to measure the thrust-time characteristics of each specimen rocket motor. This system is capable of repeatedly recording the thrust-time characteristics of rocket motors generating up to $20 \mathrm{kN}$ of maximum thrust with dispersion errors of $\pm .005 \%$. The system essentially consists of single-point $2,000 \mathrm{~kg}$ linearly defined load cell (Fig. 8) interfaced to a 12 Bit DATAQ DI-1100 Data Acquisition Unit. A precision mass measurement and accelerometer were also interfaced with the DATAQ system. This included the inertial rocket load in the measurement, thus providing a dynamic flight environment during the test. An 18-volt, transistor battery was used to excite the strain gauge circuitry in the load cell and Accelerometer. The load cell has a full-scale output of $2.0 \mathrm{mV} / \mathrm{V}$. The multiplexed signal was electrically filtered through low noise signal and power conditioning modules. The load cells wirelessly communicated the force data to the personal computer via the DI-1100. The user interface software displayed and logged the time-thrust data into an excel file for further analysis. The samples of each rocket motor for different propellant formulations were mounted in the test setup. The propellant delivered specific impulse was derived from the measured thrust-time characteristics. Several other performance parameters were subsequently calculated.

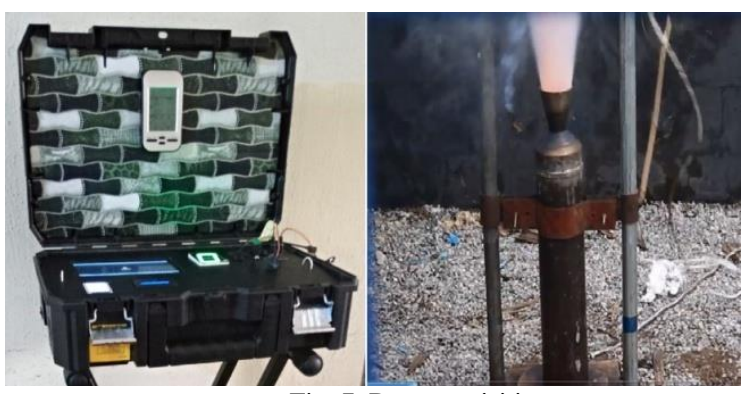

Fig. 7. Data acquisition.

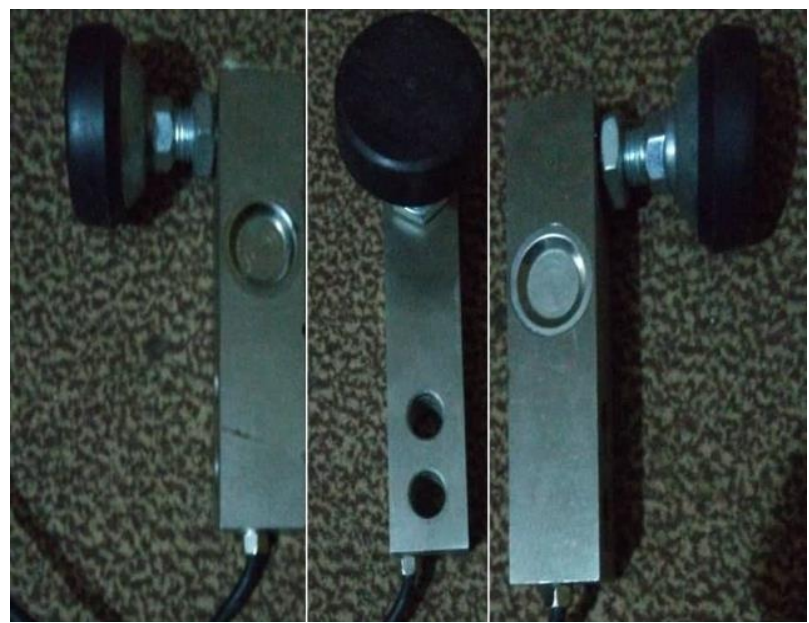

Fig. 8. Load cell (single-point 2,000 kg linearly defined load cel characterized by $0-20 \mathrm{kN}$ of force with $\pm .005 \%$ accuracy).

\section{RESULTS AND DISCUSSION}

The thrust profile from the combustion of rocket propellant made of potassium nitrate $(65 \%)$ and sucrose $(35 \%)$ in experiment 1 is presented in Fig. 9. The burning pattern and the pressure built up in the chamber were noticed to be highly sporadic. This is naturally the challenge that is always faced with this propellant formulation. The formulation has fast burning rate and poor mechanical property, thus, opening up the propellant burning area unexpectedly and subsequent generating high combustion gas flux. Several experiments using this formulation often resulted into explosion of the combustion chamber. The delivered motor average thrust, and the effective burn time were $164.15 \mathrm{~N}$ and $3.97 \mathrm{~s}$ respectively. The maximum thrust and pressure were $310.47 \mathrm{~N}$ and $0.51 \mathrm{MPa}$ respectively (Table 1).

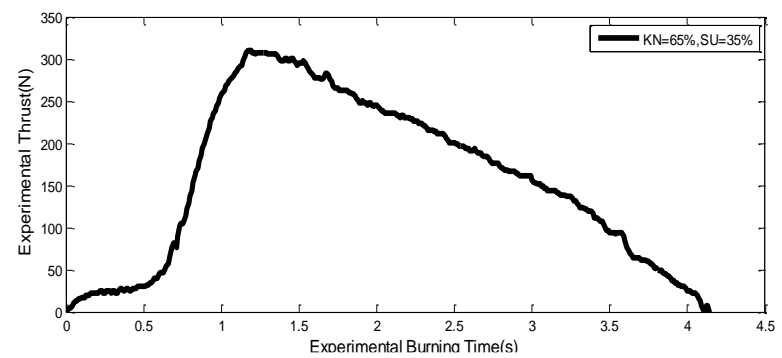

Fig. 9. Thrust profile for propellant formulation $(\mathrm{KN}=65 \%, \mathrm{SU}=35 \%)$.

TABLE 1: MEASURED MOTOR INTERNAL BALlistiC PARAMETERS

\begin{tabular}{|c|c|c|c|c|c|c|}
\hline Parameters & Expt.1 & Expt.2 & Expt.3 & Expt.4 & Expt.5 & Expt.6 \\
\hline $\begin{array}{l}\text { Propellant } \\
\text { Mass (kg) }\end{array}$ & 1 & 1 & 1 & 1 & 1 & 1 \\
\hline $\begin{array}{l}\text { Maximum } \\
\text { Thrust (N) }\end{array}$ & 310.47 & 208 & 115.59 & 115.60 & 446.79 & 140.04 \\
\hline Burn Time (s) & 3.97 & 6.53 & 9.38 & 6.76 & 3.77 & 5.89 \\
\hline $\begin{array}{c}\text { Total Impulse } \\
\text { (Ns) }\end{array}$ & 651.67 & 672.24 & 615.86 & 534.68 & 919.806 & 545.50 \\
\hline $\begin{array}{l}\text { Average } \\
\text { Thrust (N) }\end{array}$ & 164.15 & 102.95 & 65.66 & 79.09 & 243.98 & 92.62 \\
\hline $\begin{array}{c}\text { Delivered } \\
\text { Specific } \\
\text { Impulse (s) }\end{array}$ & 61.45 & 65.02 & 55.21 & 54.50 & 77.11 & 54.30 \\
\hline $\begin{array}{c}\text { Delivered } \\
\text { Characteristic } \\
\text { Velocity }(\mathrm{m} / \mathrm{s})\end{array}$ & 378.20 & 400.12 & 339.81 & 335.43 & 474.54 & $334-.2$ \\
\hline $\begin{array}{l}\text { Burn Rate } \\
(\mathrm{m} / \mathrm{s})\end{array}$ & 0.0096 & 0.0058 & 0.0037 & 0.0051 & 0.0037 & 0.0059 \\
\hline $\begin{array}{c}\text { Max Pressure } \\
(\mathrm{MPa})\end{array}$ & 0.51 & 0.344 & 0.191 & 0.251 & 0.74 & 0.23 \\
\hline
\end{tabular}

Meanwhile, the profile of the sorbitol formulation resulting from experiment 2, posed a different behaviour (Fig. 10). Both the pressure and thrust build-up was gradual, and it burns for a longer time comparing to the formulation in experiment 1 . The measured internal ballistic parameters: the motor maximum thrust, the propellant effective burn time, the motor average thrust, and maximum chamber pressure were $208 \mathrm{~N}, 6.53 \mathrm{~s}, 102.95 \mathrm{~N}$ and $0.34 \mathrm{MPa}$ respectively. 


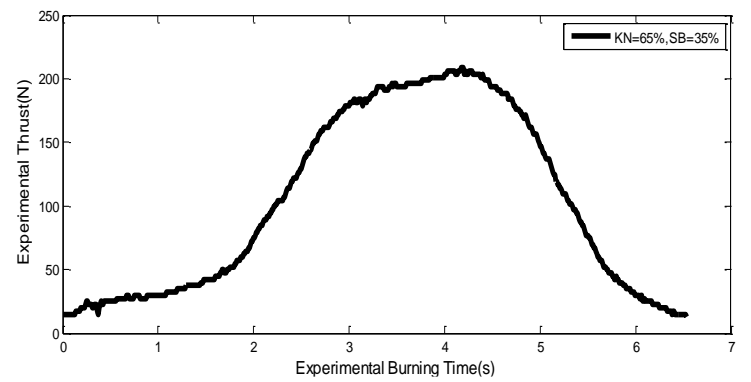

Fig. 10. Thrust profile for propellant formulation $(\mathrm{KN}=65 \%, \mathrm{SB}=35 \%)$.

The experiment 3 was meant to test the implication of the presence of an opacifier (carbon) in the combustion property. It was revealed that the motor internal ballistic parameters (the motor maximum thrust, the propellant effective burn time, the motor average thrust and maximum chamber pressure) were $115.59 \mathrm{~N}, 9.38 \mathrm{~s}, 65.66 \mathrm{~N}$ and $0.19 \mathrm{MPa}$. The performance seems to be lower compared to the previous experiments. From its profile in Fig. 11, the burning was noticed to be smoky and with the presence of some noises. Since the formulation was prepared using recrystallization method, the presence of water in the propellant was suspected and this could be the reason for a longer burn time, thus, lower thrust.

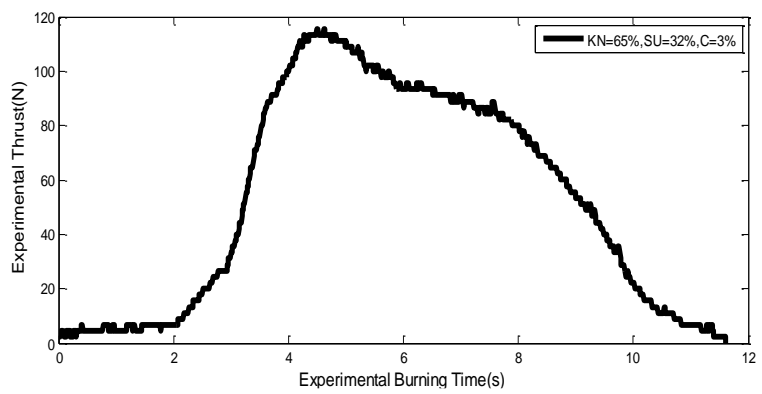

Fig. 11. Thrust profile for propellant formulation ( $\mathrm{KN}=65 \%, \mathrm{SU}=32 \%$ $\mathrm{C}=3 \%$ ).

From Fig. 12, $115.60 \mathrm{~N}, 6.76 \mathrm{~s}, 79.09 \mathrm{~N}$ and $0.251 \mathrm{MPa}$ were deduced for the motor maximum thrust, the propellant effective burn time, the motor average thrust, and maximum chamber pressure respectively. These measurements were obtained from the combustion of motor loaded with the formulation 4. The propellant ignition was sudden, and however, there were energy losses resulting into a low thrust. The improvement of formulation 4 resulted in the formulation 5 by introducing additive carbon to curb the identified energy loss in the combustion chamber. Opacifier prevents heat loss from the chamber during combustion thus resulting into a full delivery of the combustion energy. Fig. 13 , thus, gave the static profile of motor maximum thrust, the propellant effective burn time, the motor average thrust and maximum chamber pressure of 446.79 N, 3.77 s, 243.98 $\mathrm{N}$ and $0.74 \mathrm{MPa}$, respectively. It is very obvious that this formulation produced the highest thrust, and the burning was stable and smokeless. This propellant formulation has a very fast burning characteristic and thus very high pressure than the previous formulations. This characteristic is noticed in spite of the highest thrust as a big challenge. Therefore, outstanding effort is required from a rocket motor designer to manage this sudden pressure built-up, in order to prevent motor explosion.

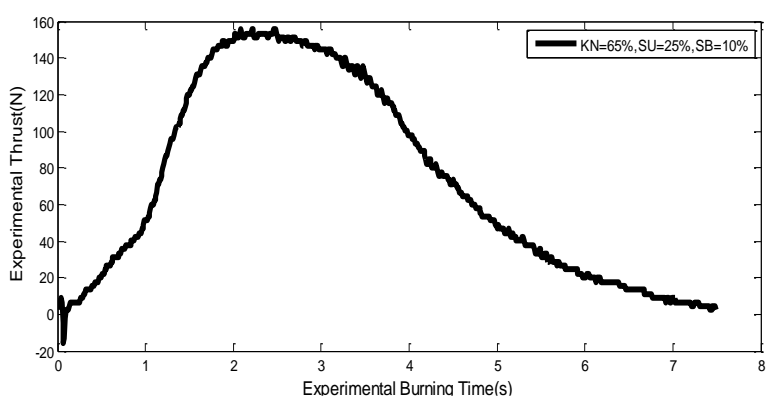

Fig. 12. Thrust profile for propellant formulation $(\mathrm{KN}=65 \%, \mathrm{SU}=25 \%$, $\mathrm{SB}=10 \%)$.

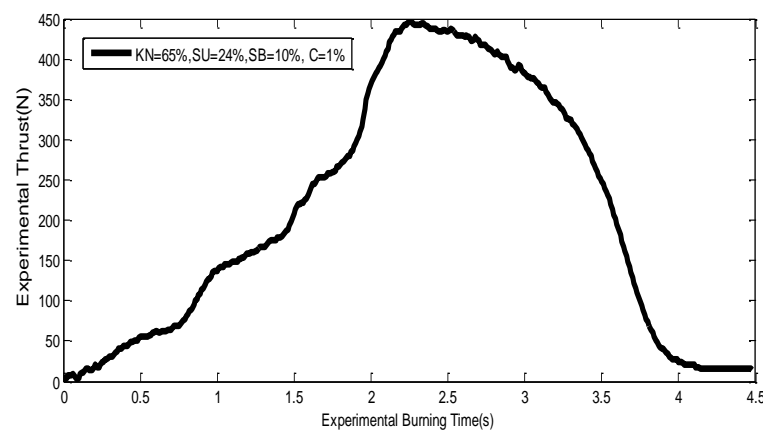

Fig. 13. Thrust profile for propellant formulation $(\mathrm{KN}=65 \%, \mathrm{SU}=24 \%$, $\mathrm{SB}=10 \%, \mathrm{C}=1 \%$ ).

Performance parameters from experiment 6 (Fig. 14) were $140.04 \mathrm{~N}, 5.89 \mathrm{~s}, 92.62 \mathrm{~N}$ and $0.23 \mathrm{MPa}$ for maximum thrust, the propellant effective burn time, the motor average thrust and maximum chamber pressure respectively. A stable burning and relatively less smoky plume were noticed. Meanwhile, the Fig. 15 depicts the comparative behaviour of all thrust profiles measured from all experiments.

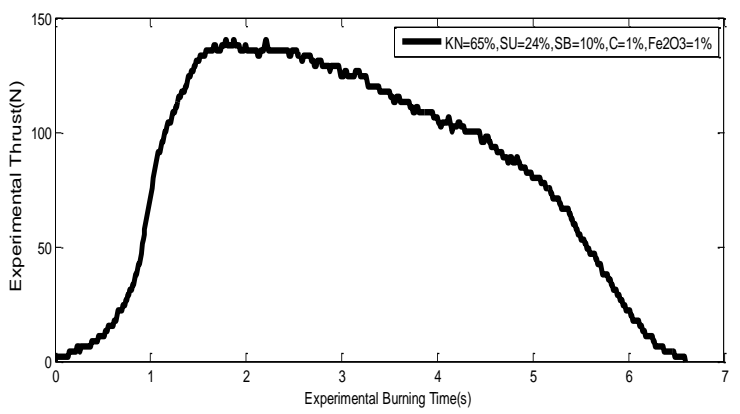

Fig. 14. Thrust profile for propellant formulation $(\mathrm{KN}=65 \%, \mathrm{SU}=30 \%$, $\mathrm{SB}=3 \%, \mathrm{C}=1 \%, \mathrm{Fe} 2 \mathrm{O} 3=1 \%$ ).

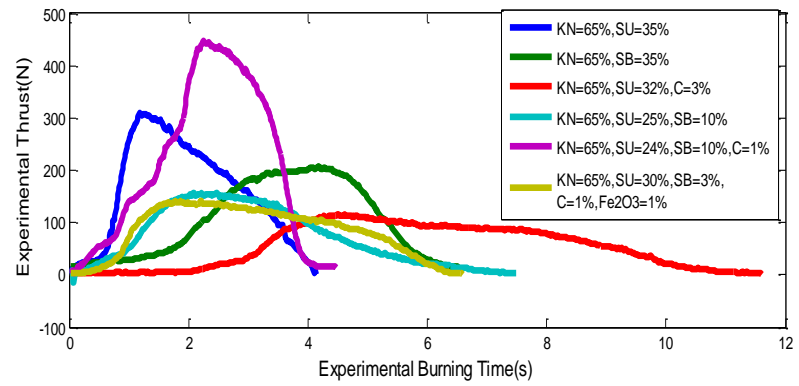

Fig. 15. Thrust profiles for all the tested formulations.

The comparative results of the four static tests and a flight test are shown in Table 2. The dynamic thrust value $(1081 \mathrm{~N})$ was slightly higher than the average static thrust value of $946.88 \mathrm{~N}$. However, the propellant burn time of $5 \mathrm{~s}$ 
was measured during rocket flight as compared to the $6.77 \mathrm{~s}$ measured during static combustion. This actually accounts for the thrust values obtained. The difference in the propellant specific impulse is evident, in that there were energy losses during the static combustion. This could be traced to the inconsistencies in the propellant manufacturing or losses through the clamp design and its fabrication for holding the motor during tests or probably leakages through the bulkhead of the motor.

TABLE 2: MOTOR STATIC AND FLIGHT PARAMETERS

\begin{tabular}{|c|c|c|c|c|c|c|c|}
\hline \multirow[b]{2}{*}{ Experiments } & \multicolumn{5}{|c|}{ Static Tests Values (from the Load Cell readings) } & \multirow{2}{*}{$\begin{array}{c}\text { Launch } \\
\text { Values }\end{array}$} & \multirow{2}{*}{$\begin{array}{l}\% \text { increase } \\
\text { or decrease }\end{array}$} \\
\hline & 1 & 2 & 3 & 4 & Av. Val. & & \\
\hline Mass of Propellant (kg) & 7.58 & 7.68 & 7.6 & 7.4 & 7.57 & 7.58 & 0.12 \\
\hline Maximum Thrust (N) & 2066.02 & 1483.83 & 1391.93 & 1313.12 & 1563.72 & 1781.87 & 13.95 \\
\hline Prop. Eff. Burn Time (s) & 5.42 & 7 & 8.07 & 6.6 & 6.77 & 5 & -26.15 \\
\hline Total Impulse (Ns) & 6778.14 & 6136.15 & 6332.52 & 5779.28 & 6256.52 & 8196.90 & 31.01 \\
\hline Average Thrust (N) & 1250.58 & 876.59 & 784.70 & 875.65 & 946.88 & 1081 & 14.16 \\
\hline Specific Impulse (s) & 91.14 & 81.45 & 84.94 & 79.61 & 84.28 & 110.23 & 39.79 \\
\hline Max. Chamber Press. (MPa) & 1.03 & 0.83 & 0.75 & 0.75 & 0.84 & 0.74 & -11.90 \\
\hline Av. Chamber Press. (MPa) & 0.62 & 0.49 & 0.42 & 0.50 & 0.58 & 0.68 & 17.74 \\
\hline
\end{tabular}

\section{CONCLUSIONS}

The designed dual-fuel propellant formulation (MODKNERK) has successfully established an appropriate proportion as a trade-off for both weakness and strength of both sucrose and sorbitol as fuels in solid rocket propellant. Also, the effects of propellant additives in improving its ballistic indices have been established. The MODKNERK, was established to produce a most efficient motor and with the full delivery of its ballistic energy. Also, the ballistic and rocket motor efficiency of a lower energetic rocket motor was also established to be aided by starting the ignition of such motor with fast burning rocket dual-fuel propellant.

However, it is recommended that this investigation be extended in the future to emission analysis of the developed dual-fuel sugar-based rocket propellant. Also, this paper focuses on improving the ballistic performance of KNSB motor by starting the ignition with the designed dual-fuel propellant. However, the performance implications of the dual-fuel propellant, being placed in other positions in the motor have not been established. Therefore, the future work is suggested to focus on these.

\section{ACKNOWLEDGEMENT}

We appreciate the entire rocket propellant unit, Centre for Space Transport and Propulsion, Epe, Lagos, Nigeria, for their efforts during designs and development of the rocket propellants. Special regard is directed to the management and the entire engineering team of the Centre for the entire assistant during static tests and rocket launch. We also, appreciate the management of National Space Research and Development Agency, for their support during the investigations.

\section{DISCLOSURE STATEMENT}

In accordance with our ethical obligation as researchers, we declare that this work was not financially sponsored by any organization nor operate under any research grant.

\section{REFERENCES}

[1] Sidhant Singh (2013). Solid Rocket Motor for Experimental Sounding Rockets. Advances in Aerospace Science and Applications, Volume 3, Number 3, pp. 199-208.
[2] Singh, D. A., (2015). Sugar Based Rocket Propulsion SystemMaking, Analysis \& Limitations. International Journal of Engineering Trends and Applications (IJETA, Vol., 2, Issue 5.

[3] Nakka, R. Richard Nakka's Experimental Rocketry Site. 27 July 2008. 06 Jan. 2009 <http://www.nakka-rocketry.net/>.

[4] Stuart Leslie and James Yawn Proposal for the Inclusion of KNO3/Sugar Propellants to TRA. Submitted to: Ben Russell and the TRA Board of Directors October 4, 2002 TRA, October 4, 2002.

[5] Rodić, V. and Petrić, M. (2004). The Effect of Additives on Solid Rocket Propellant Characteristics. Scientific Technical Review, Vol LIV, No.3-4.

[6] George, S. Q. D. And Rene F. B. G. (2019) Combustion Simulation Analysis of Solid Propellant Sucrose/Potassium Nitrate for Rocket Engine. Brazilian Journal of Technology, Vol 2, No 1.

[7] Yang, V., Brill, T.B. And Ren, W.Z. (2000). Solid Propellant Chemistry, Combustion and Motor Interior Ballistic. Progress in Astronautics and Aeronautics, Volume 185.

[8] Galarza C., Pulido D., Urrego P. J., Alejandro, R. F. (2017). Design of a Candy Propellant Rocket Motor by a Computer Aided System and Its Performance in Static Testing. $7^{\text {Th }}$ European Conference for Aeronautics and Space Sciences (Eucass). Doi: 10.13009/Eucass2017-388.

[9] Jaafar, M., Ali, W.K.W., Dahalan, M.N., Mamat, R., Campus, M. \& Kuantan, P. 2004, "Development of solid rocket propulsion system at UTM", Jurnal Mekanikal, vol. 18, pp. 111-121.

[10] Mukesh R., Sivasubramaniyam R., Elangovan R. R., Abhinaya Sree R., Harish R., Rajashree D., Satish Kumar Kanhar (2017) Studies on the Internal Ballistics of Composite Solid Rocket Propellants Incorporating Nano-Structured Catalysts. Advances in Aerospace Science and Technology, 2, 48-72.

[11] Ahmed Ibrahim, YeongRyu, Mir Saidpour, (2015). Stress Analysis of Thin-Walled Pressure Vessels. Mechanical Engineering Technology, Farmingdale State College, Farmingdale, New York, USA.

[12] Sean D. W. (2015). High Regression Rate Hybrid Rocket Fuel Grains with Helical Port Structures. A thesis submitted in partial fulfillment of the requirements for the degree of Master of Science in Aerospace Engineering.

[13] Shmakov, A.G., Korobeinichev, O.P. and Bol'shova, T.A. (2002). Combustion, Explosion, And Shock Waves, 38: 284 Https://Doi.Org/10.1023/A:1015697618376.

[14] Hadzik, J., Koślik, P., Wilk, Z., Frodyma, A., Habera, L. (2017). Experimental Study on Ammonium Nitrate(V)-based Solid Propellants for Fracturing Wells. Cent. European Journal of Energy Mater, 14(3): 660-674.

[15] Carter, M.G. (2008). An investigation into the combustion and performance of small solid-propellant rocket motors. Final Thesis Report. University of New South Wales, 1-34.

[16] Vesna R. and Mirjana P. (2004). Effect of Additives on Solid Rocket Propellant Characteristics. Scientific Technical Review, Vol.LIV, No.3-4. UDK: 623.4.081.1:66.022.387 COSATI: 21-09

[17] Justyna H., Piotr, K. Zenon, W., Antoni F., Łukasz H. (2017). Experimental Study on Ammonium Nitrate Based Solid Propellants for Fracturing Wells. Central European Journal of Energetic Materials., 14(3): 660-674

[18] Foltran, A.C., D. F. Moro, N. D. Pereira da Silva, A. E. Gonçalves Ferreira, L. K. Araki, C. H. Marchi. (2015). Burning Rate Measurement of KNSu Propellant Obtained by Mechanical Press. $J$. Aerosp. Technol. Manag., São José dos Campos, Vol.7, No 2, pp.193-199. 
[19] Kumar, M. P. and Palekar S. G. (2015). Design and Performance Analysis of Aluminized Sugar Aided Rocket Propulsion Using MATLAB. International Journal of Science and Research (IJSR) Volume 4 Issue 10, October 2015.

[20] Olaoye, O. S. And Abdulhafeez O. A., (2014). Design and Performance Characteristics of a Rocket Using Potassium Nitrate and Sucrose as Propellants. International Journal of Science and Research (IJSR) Volume 3 Issue 8.

[21] Mohammad Norshim Bin Mohamed Hashim. 2012. Development of Solid Rocket Propellant. Thesis Submitted in Fulfillment of the Requirements for the Award of the Degree of Bachelor of Mechanical Engineering with Automotive Engineering Faculty of Mechanical Engineering University of Malaysia Pahang.

[22] Henry, C. And Norman S.C. 2012. Performance of Solid Propellant Containing Metal Additives. AIAA, Vol 3, No 2.

[23] Adeniyi, G.O., Adeniran, J.A, Adesanmi, A.J., Akeredolu, F.A. an Sonibare, J.A. (2018). Optimisation and Performance Evaluation of an Environmentally Friendly Rocket Composite Propellant. Indian Chemical https://doi.org/10.1080/00194506.2018.1509239.

Engineer.

24] Jimmie C. O., James L. S., Maria D. and Matthew P. (2014). FuelOxidizer Mixtures: Their Stabilities and Burning Characteristics. International Journal of Energetic Materials and Chemical Propulsion, 13 (6): 517-557.

[25] Rafaela, B., Douglas M. S.Tiago B. G. And Tânia M. (2016). Valuation of Rocket Propulsion Performance Using Potassium Nitrate/Sucrose and Aluminum/Ice as Propellants. Journal of Basic and Applied Research International , 19(3):152-156.

[26] Whitmore S.A. (2017). Advantages of Using Additive Manufacturing to Build "Green"Fuels for Hybrid Propulsion. International Journal of Astronaut Aeronautical Engineering.

[27] Vairat, S. Gaikwad, S, Muneshwar, R. (2017). Design and Manufacturing of Cloud Seeding Rocket. International Journal for Scientific Research \& Development| Vol. 5, Issue 05, 2017 | ISSN (online): 2321-0613.

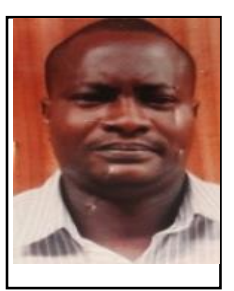

Gbadebo Omoniyi Adeniyi is the head, Rocket Propellant Unit, Centre for Space Transport and propulsion, Epe, Lagos, Nigeria. He has $\mathrm{PhD}$ in Chemical Engineering from Obafemi Awolowo University, Ile-Ife, Nigeria. Masters in Aerospace Instrumentation from SUAI, Russian Federation and Masters in Chemical Engineering from O.A.U, IleIfe. He specializes in rocket propulsion and air quality analysis. He is a registered member of the (COREN - R41651). Council for the Regulation of Engineering in Nigeria.

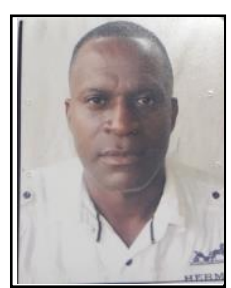

Ikechukwu Nkere is a staff of Rocket Propellant Unit, Centre for Space Transport and Propulsion, Epe, Lagos. He has a B.Eng. Chemical Engineering from Enugu State University of Science and Technology. He specializes in design, formulation, characterization and manufacturing of Propellant Grain for Rocket Propulsion.

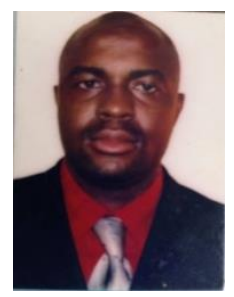

Adetoro M.A.L obtained his Doctoral degree in System Engineering with a specialization in control theory and artificial intelligence. Since 2003, he has been an Aerospace Research Engineer at the national Space Research and Development Agency, Nigeria. The spheres of his main interests are mathematical modeling, motion control, automatic control system, integrated system and aerospace electronics. He has involved himself in many R\&D works in the aerospace instrumentation field and has excellent experience in

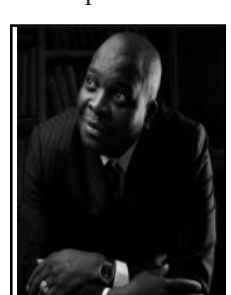
international scientific collaboration with colleagues within and outside Nigeria.

Olusegun S. Sholiyi was born in Ifo, Ogun state, Nigeria, in 1970. He received his Bachelor of Engineering degree in electrical engineering from University of Ilorin, Kwara State, Nigeria in 1992. He obtained the Master of Science degree in microwave engineering and wireless subsystems design in 2008 from University of Surrey, UK. In 2013 and 2014, he also received the Master of Science and $\mathrm{PhD}$ degrees in electrical engineering respectively, from the University of Alabama in Huntsville, United States of America. His research interests include antenna propagation, numerical methods in electromagnetics, characterization of electromagnetic properties of materials, microwave devices. In 2015, he started developing interest in guidance, navigation and control (GNC) of aerospace vehicles. Dr. Sholiyi is currently a Director/Chief Executive at The Centre for Space Transport and Propulsion in National Space Research and Development Agency, Nigeria. He is also a facilitator and project supervisor at National Open University of Nigeria. 